\title{
The Role of Parenting Style in Youth Sport Talent
}

\author{
Adhim Rahtawu \\ Department of Sport Science \\ Universitas Sebelas Maret \\ Surakarta, Indonesia \\ rahta27@gmail.com
}

\author{
Agus Kristiyanto \\ Department of Sport Science \\ Universitas Sebelas Maret \\ Surakarta, Indonesia \\ aguskriss@yahoo.co.id
}

\author{
Sapta Kunta Purnama \\ Department of Sport Science \\ Universitas Sebelas Maret \\ Surakarta, Indonesia \\ saptakunta_p@yahoo.com
}

\begin{abstract}
- the idea of this study which is the importance of parenting style to adolescents in sports talent scouting has barely been considered. This research is aimed at identifying and comparing sports talent of teenagers in terms of parenting style. The method of this research was the use of survey and quantitative approach. Population was taken from teenagers in Sragen within the age bracket of 16-17 years. Samples amounted to 184 respondents. It made use of descriptive data analysis through the execution of a guidance talent test with sport search. Result would precentage with chi squared. The results showed the comparison of sport talent of children with authoritative type, democratic, permissive in a row of (high jump 7\%, 14\%, 11\%), (shot put and discus throw 2\%, 1\%, 2 $\%$ ), (diving 4\%, 22\%, 18\%), (gymnastics 5\%, 11\%, 10\%), (sprint 7\%, 16\%, 17\%), (distance running 1\%, 11\%, 14\%), (trampolining $1 \%, 6 \%, 4 \%$ ). There was no significant difference between sport talent in authoritarian, democratic, and permissive types. Fcount $\mathbf{1 0 . 0 3}$ is smaller than Ftable 21,026. The conclusion was, the most dominant sport with authoritarian type were athletics-sprint running and athleticshigh jump. Democratic type was sports diving, while in children who have permissive type was also diving.
\end{abstract}

Keywords - sport talent identification, sport parenting.

\section{INTRODUCTION}

Parents are the key players in supporting their own teens and children to do sport and physical activity [1] Parents interaction and participation in both activities have huge impacts on teens' willingness to get involved in the teen's sports. [2-4] Most parents who often do physical activity are most likely to have children who are interested in sports. [5] Thus, teens experiences in sport activity give them chances to improve their quality, which could possibly lead to their athletic psychology moving beyond the domain of physical ability. It is due to the fact that parents behavior is easily inherited by those teens. A good example displayed by parents in sport activity would as a resultant effect, have a good impact on the teenagers [6]

Every parent has their own diverse ways of nurturing their children based on their demand and support [7] There are three kinds of parenting related to this dimension. They are; authoritarian parenting, in which parents strive for their children without giving them any kind of support, democratic parenting, in which parents give both support and demand equally, and permissive parenting, in which parents give support without requiring any demand. [8] By applying these different kinds of parentings, parents have an in depth connection with every teenager athlete in their sport activity - this includes parental pressure \& involvement, and also family support.[9] Parental involvement is conducted in the space of time of conducting those sport activities or after finishing them. [10] A very interesting factor is the case of home parenting which in the time of practice changes teenagers' will to actively be involved in the sport activity [11] The will to get associated with routine sport activity through parental support and aptitude supervision could not be properly influenced from the early age directly or indirectly done by parents [12]

Talent identification is a means to effectively locate the talented and potential athletes in their early age so as to get them improved in a particular field of sport for the achievement of optimum performance [13] Research has shown the significance of these aptitudes in aiding athletes reach the Olympic level [14] Accurate aptitude supervision in their specialized field of sport from an early age could aid athletes in reaching the highest peak of achievement [15], [16] Research shows that some teens end up dropping out of the training and sport activity majorly due to their difficulty in adaptation based on their very own ability. Here, the role of parents is to understand the exact parenting method which can precisely determine a teen's sport talent. [17-19]

Till date, there is no specific organization or institution in the local training centers, such as in Sragen regency, held by prime organization or private company which specifically is aimed at carrying out aptitude supervision. That is why, aptitude supervision program, identified and selected talented athletes training could be done as efforts towards advancing interest and achievement in sport. In a recent observation in Sragen regency it was discovered that children talent in sport, based on their parental types are never identified accurately. Except the indicator for talent identifying, there is no other document to give clarity on it. Recognizing these facts, this research conducted so as to identify the kinds of sport aptitude the children might have, based on the parental types. This research expected to become a reference point for the next research on the advancement of sport achievement and athlete supervision.

\section{METHOD}

This research employed the use of survey method with quantitative approach. Samples of this study were 184 people, consisting of adolescents aged 16 - 17 years in Sragen. Furthermore parent style data was taken through a questionnaire, which has been empirically tested and validated by the subject for talent data. It is taken through ten points of aptitude test including height measurement, body mass measurement, sitting height measurement, arm span, catch, basketball throw, vertical jump, agility run, 40 meters sprint, and shuttle run [20] After the data of parenting and talent test has been completed, then analyzed using Sport search application, the results were displayed after all sports 
talent test data entry. To determine the possibility of a significant difference or not, it should be compared with ChiSquare count which is examined with Chi-Square table at degrees of freedom (dk) and significance level. [21]

\section{RESULT}

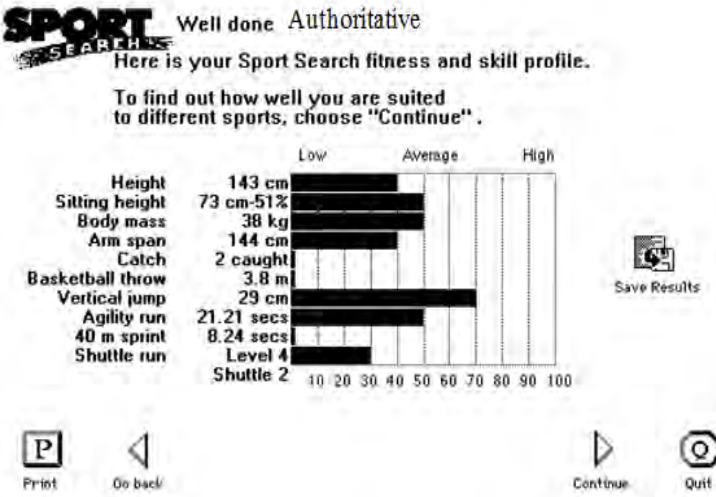

The result of MFT indicated level 4 shuttle 2.

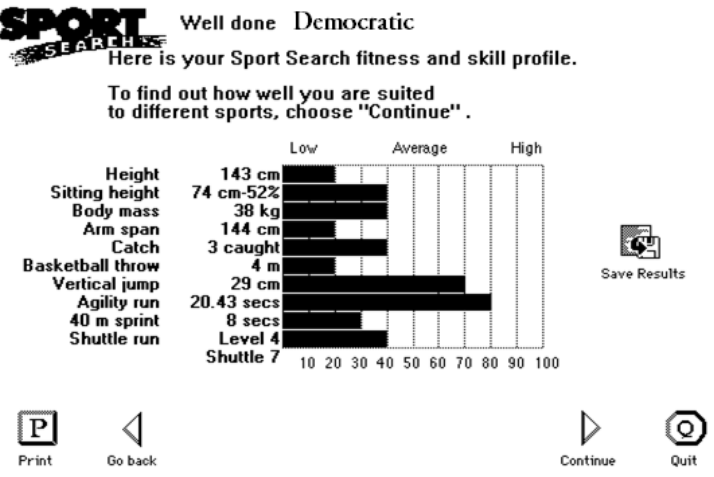

The result of MFT indicated level 4 shuttle 7.

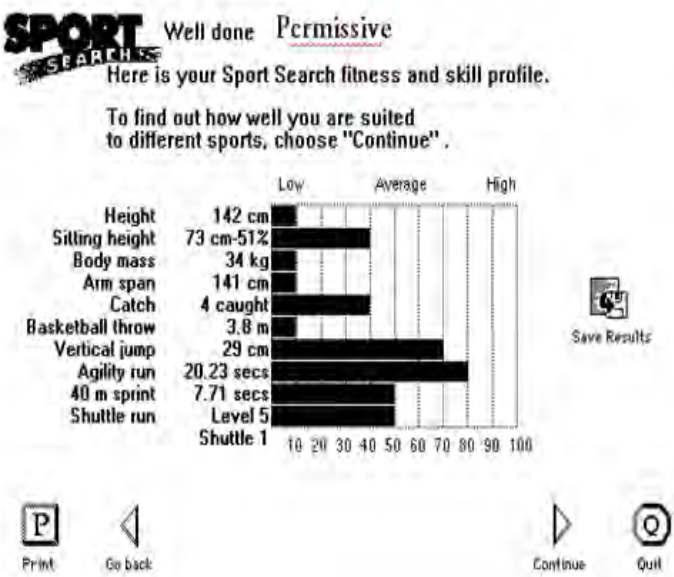

The result of MFT indicated level 5 shuttle 1.

Fig. 1. This research indicated the types of parenting style in Sragen which are authoritarian, democratic, and permisive parenting style. it shows the average scores owned by the three groups.

Based on the average score calculation of the three categories of parenting style in Sragen within the age bracket of adolescents, if calculated based on the sport search application then the result can be seen in the frequency table below:

TABLE I. DOMINANT DISTRIBUTION OF SPORTS FREQUENCY IN A TEENAGER WHO HAS PARENTING STYLE (AUTHORITARIAN) IN SRAGEN

\begin{tabular}{llcl}
\hline No & \multicolumn{1}{c}{ Type of sport } & Frequency & Percentage \\
\hline 1 & Athletics - Sprint Running & 7 & $26 \%$ \\
\hline 2 & Athletics - High Jump & 7 & $26 \%$ \\
\hline 3 & Gymnastics & 5 & $18 \%$ \\
\hline 4 & Diving & 4 & $15 \%$ \\
\hline 5 & Athletics - Shot Put And Discus & 2 & $7 \%$ \\
\hline 6 & Athletics - Distance Running & 1 & $4 \%$ \\
\hline 7 & Trampolining & 1 & $4 \%$ \\
\hline \multicolumn{2}{c}{ Total } & 27 & $100 \%$ \\
\hline
\end{tabular}

From the frequency distribution table shown above, a teenager with authoritarian style can be identified in sport search which is indicated in the overall top recommended sports with the possibility of bring prioritized in the teenagers. There are some sports athletics - high jump and athletics - sprints which displays $26 \%$ of samples and are the most dominant. In third place there is gymnastics sport which shows $18 \%$ of sample, then there is sport diving which shows $15 \%$ of the sample, athletics sport - shot put and discus throws get $7 \%$ of samples. At the bottom there are athletics - distance running and trampolining, which both indicates $4 \%$ of the sample. In conclusion, the dominant sport for children with authoritarian style in Sragen having a whopping percentage of $26 \%$ is athletics sports - high jump and athletics - sprint running.

TABLE II. DOMINANT DISTRIBUTION OF SPORTS FREQUENCY IN A TeEnager With PARENTING STYLE (DEMOCRATIC) IN SRAGEN

\begin{tabular}{llll}
\hline No & \multicolumn{1}{c}{ Type of sport } & Frequency & Percentage \\
\hline 1 & Diving & 22 & $27 \%$ \\
\hline 2 & Athletics - Sprint Running & 16 & $20 \%$ \\
\hline 3 & Athletics - High Jump & 14 & $17 \%$ \\
\hline 4 & Gymnastics & 11 & $14 \%$ \\
\hline 5 & Athletics - Distance Running & 11 & $14 \%$ \\
\hline 6 & Trampolining & 6 & $7 \%$ \\
\hline 7 & Athletics - Shot Put And Discus & 1 & $1 \%$ \\
\hline & Total & 81 & $100 \%$ \\
\hline
\end{tabular}

From the frequency distribution table above, teenagers with the democratic parenting style it was indicated that the overall top recommended sport was diving sport, indicating $27 \%$ of the sample or 22 out of 81 teenagers. In second place is athletics - sprint running sport which gets $20 \%$ of the sample. In third place is athletics - high jump that shows $17 \%$ of the sample or 14 teenagers. Furthermore, there are gymnastics and athletics - distance running which both show $14 \%$ of the sample, Trampolining is in the next in line with $7 \%$ of the sample being 6 people. At the bottom there is 
athletics - shot put and discus throw, which has a percentage of $1 \%$ of the sample.

The conclusion therein was that the dominant sport for children who have democratic parenting type in Sragen, with the largest percentage of $27 \%$ is sports diving.

TABLE III. DOMINANT DISTRIBUTION OF SPORTS FREQUENCY IN A TEENAGER WHO HAS PARENTING STYLE (PERMISSIVE) IN SRAGEN

\begin{tabular}{llcl}
\hline No & \multicolumn{1}{c}{ Type of sport } & Frequency & Percentage \\
\hline 1 & Diving & 18 & $24 \%$ \\
\hline 2 & Athletics - Sprint Running & 17 & $23 \%$ \\
\hline 3 & Athletics - Distance Running & 14 & $18 \%$ \\
\hline 4 & Athletics - High Jump & 11 & $14 \%$ \\
\hline 5 & Gymnastics & 10 & $13 \%$ \\
\hline 6 & Trampolining & 4 & $5 \%$ \\
\hline 7 & Athletics - Shot Put And Discus & 2 & $3 \%$ \\
\hline \multicolumn{2}{c}{ Total } & 76 & $100 \%$ \\
\hline
\end{tabular}

From the frequency distribution table above, the type of permissive parenting style can be identified in sport search which is indicated in the overall top recommended sports and can be prioritized are several sports like diving sports with $24 \%$ of the sample. Second place is athletics sport - sprint running shows $23 \%$ of the sample, next is athletics - distance running exercise with $18 \%$ of the sample. In fourth place is athletics - high jump sport which shows $14 \%$ of the sample. In the fifth position is gymnastics which gets a percentage of $13 \%$ of the sample. The next exercise is trampolining, with $5 \%$ of the sample. Athletics - shot put and discus throw has a percentage of $3 \%$. It can therefore be concluded upon based on research result that the dominant sport for teenagers who have permissive style in Sragen with $24 \%$ is sports diving.

TABLE IV. RECAPITULATION OF FREQUENCY DISTRIBUTION OF SPORTS FROM PARENTING STYLE IN SRAGEN.

\begin{tabular}{|c|c|c|c|}
\hline No & Sports & \multicolumn{2}{|c|}{ (Authoritative) (Democratic) (Permisive) } \\
\hline 1 & Diving & 22 & 18 \\
\hline 2 & Athletics - Sprint Running & 16 & 17 \\
\hline 3 & Athletics - High Jump & 14 & 11 \\
\hline 4 & Gymnastics & 11 & 10 \\
\hline 5 & Athletics - Distance Running & 11 & 14 \\
\hline 6 & Trampolining & 6 & 4 \\
\hline 7 & Athletics - Shot Put And Discus & 1 & 2 \\
\hline & Total & 81 & 76 \\
\hline
\end{tabular}

Based on the recapitulation table of frequency distribution diving in Sragen, discovering the potential of athletes in the sport platform of diving in Sragen is highly recommended for teenagers who have democratic parenting style. This is due to its accumulation of the greatest result which is 22 teenagers. Secondly are teenagers who receive permisive parenting style and are as many as 18 . In third place there are teenagers who recieve authoritarian parenting style, which displays a sum total of 4 teenagers from the total sample. While searching for athletes athletics - sprint running seedlings in sragen, the most recommended type are teenagers who have permisive parenting style, therefore possesing the greatest result, 17 adolescents. The second is that of teens who have a democratic parenting style and includes a big figure of 16 teenagers and in third place are teenagers who have authoritarian parenting style, resuting in an aggregate of 7 teenagers from the total sample. High jump athletes in Sragen, the most recommended are teenagers who recieve a democratic style and the greatest result which is 14 teenagers. In second place is a child who has permisive style and makes up for as many as 11 teenagers. In third place are tennagers with an authoritarian style, which has a total 7 teenagers from the sample. Scouting for seeds of gymnastic athletes in Sragen has the highest level potential but is encouraged for a teenager who has the democratic parenting style due to its sum total of 11 teenagers. second is a teenager who has received the permisive parenting style and is equavalent to 10 teenagers. In third place is a teenager who recieves an authoritarian parenting style, with a figure of 5 teenagers from the total sample. Athletics - distance running is highly proposed for teenagers who have the permisive parenting style due to its capacity of 14 teenagers, the second being a child who has democratic parenting style with 11 teenagers, and third being teenager who receives authoritarian parenting style and gets only 1 teenager of the total sample. Furthermore, in the trampoline sport, trampolining is highly recommended for a teenager who has democratic parenting style due to its result of 6 teenagers, the second, a child who recieves the permis.ive parenting style gathered as many as 4 teenagers and in third place is the child who recieves authoritarian parenting style, getting only 1 teenager from the total sample. Athletic shot put and discus throws are more recommended for the authoritarian parenting style and permisive due to its equal results of 2 teenagers, after it being a child who got democratic parenting style and is as much as 1 teenager from the total sample.

TABLE V. RECAPITULATION OF DATA ON DIFFERENT PARENTING STYLES to YOUTH SPORTS TALENT.

\begin{tabular}{|c|c|c|c|c|c|c|}
\hline No & Cell & $f_{0}$ & $f_{h}$ & $f_{0}-f_{h}$ & $\left(f_{0}-f_{h}\right)^{2}$ & $\left(f_{0}-f_{h}\right)^{2}: f_{h}$ \\
\hline 1 & $\bar{A}$ & 4 & 6,45 & $-2,45$ & 6,00 & 0,93 \\
\hline 2 & B & 22 & 19,36 & 2,74 & 6,96 & 0,35 \\
\hline 3 & $\mathrm{C}$ & 18 & 18,17 & $-0,17$ & 0,02 & 0,00 \\
\hline 4 & D & 7 & 5,86 & 1,14 & 1,29 & 0,22 \\
\hline 5 & $\mathrm{E}$ & 16 & 17,6 & $-1,6$ & 2,56 & 0,14 \\
\hline 6 & F & 17 & 16,52 & 0,48 & 0,23 & 0,01 \\
\hline 7 & $\mathrm{G}$ & 7 & 4,69 & 2,31 & 5,33 & 1,13 \\
\hline 8 & $\mathrm{H}$ & 14 & 14,08 & $-0,08$ & 0,00 & 0,00 \\
\hline 9 & I & 11 & 13,21 & $-2,21$ & 4,88 & 0,36 \\
\hline 10 & $\mathrm{~J}$ & 5 & 3,81 & 1,19 & 1,41 & 0,37 \\
\hline 11 & $\mathrm{~K}$ & 11 & 11,44 & $-0,44$ & 0,19 & 0,01 \\
\hline 12 & L & 10 & 10,73 & $-0,73$ & 0,53 & 0,04 \\
\hline 13 & $\mathrm{M}$ & 1 & 3,81 & $-2,81$ & 7,89 & 2,07 \\
\hline 14 & $\mathrm{~N}$ & 11 & 11,44 & $-0,44$ & 0,19 & 0,01 \\
\hline 15 & $\mathrm{O}$ & 14 & 10,73 & 3,27 & 10,69 & 0,99 \\
\hline 16 & $\mathrm{P}$ & 1 & 1,61 & $-0,61$ & 0,36 & 0,22 \\
\hline 17 & Q & 6 & 4,84 & 1,16 & 1,34 & 0,27 \\
\hline 18 & $R$ & 4 & 4,54 & $-0,54$ & 0,29 & 0,06 \\
\hline 19 & $\mathrm{~S}$ & 2 & 0,73 & 1,27 & 1,61 & 2,20 \\
\hline 20 & $\mathrm{~T}$ & 1 & 2,2 & $-1,2$ & 1,44 & 0,65 \\
\hline 21 & $\mathrm{U}$ & 2 & 2,06 & $-0,06$ & 0,00 & 0,00 \\
\hline \multicolumn{6}{|c|}{ Chi-Square Hitung } & 10,03 \\
\hline
\end{tabular}

To check for a significant difference, then it should compare Chi-Square count with Chi-Square table at degrees 
of freedom $(\mathrm{dk})$ and a certain level of significance. $\mathrm{dk}$ on the above calculation is $($ line - 1$)($ column -1$)=(7-1)(3-1)=12$. While the significance level used is $5 \%$ with $\mathrm{dk}=12$, the value of Chi-Square table is 21.026 . Because $10.03<21,026$ the difference is not significant. Gotten from the result of sport based on parenting style, the following step was given to analyze the quality test of youth sport talent that are classified into five categories based on norm. Very potential as potential athlete (VP) potential as potential of athlete $(\mathrm{P})$ quite potential as potential athlete (QP) less potential as potential athlete (KP) not potential as athlete candidate (TP) Once matched, it is adjusted to the age and gender of each student in the table on the norm of the Crude Score with the $\mathrm{T}$-Score, then summed and matched into the category norm. Of all the total samples used, it can be classified as:

\section{TABLE VI. RESUlts OF QUALITY TEST OF YOUTH SPORT}

\begin{tabular}{clccc}
\hline No & Category & Authoritative & Democratic & Permisive \\
\hline 1 & Very Potential & 8 & 1 & 2 \\
\hline 2 & Potential & 21 & 22 & 18 \\
\hline 3 & Quite Potential & 28 & 34 & 27 \\
\hline 4 & Less Potential & 4 & 5 & 14 \\
\hline 5 & Not Potential & - & - & - \\
\hline & Total & 61 & 62 & 61 \\
\hline
\end{tabular}

TALENT IN AGE 16-17 YeARS.

This study focus on aspects of the parenting style which can be divided into 3 styles; authoritarian, democratic and permissive. The results can be presented in the form of bar charts as below:

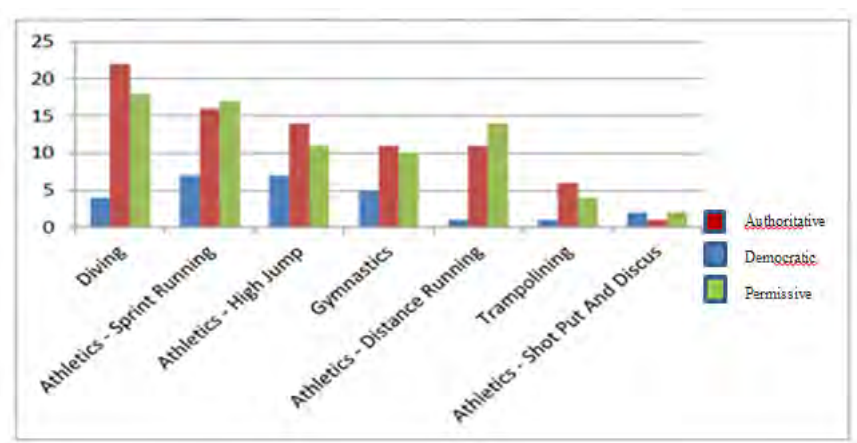

Fig. 2. Bar chart Comparison of Sports Talent Identification in Adolescents within Sragen who receive different Parenting Style.

For other reviews on the type of parenting style that each child receives; athletics - sprint running and athletics - high jumps both dominate a teenager who has an authoritarian parenting style. As for teenagers who have the democratic and permisive style, they have the same dominant sport which is platform diving.

\section{DISCUSSION}

The increasing demand for adolescents to succeed in their field of sport talent identification at an early age solely needs to prepare the athlete with the best capability.[22] The family is the closest relationship for teens who may know the desire and capability in sports activities.[23] One of the closest family members are elderly. The results of the research shows that parents' influence towards the child's mental well being in sporting activities is huge because older people have the major role of giving support or demands.[24] Based on the research objectives, different parenting style gives an overview on sporting talent in detail which is centered around an adolescent.

Development of sports talent which has been identified at an early age should be consistently observed through attention in parents during training to become a professional athlete.[25][26] The positive effects which the results of this research are able to provide makes it easier to discover the characteristics of proper parenting for teenage talent in accordance with appropriate sports.[27] Based on the results of the data retrieval questionnaire form, parents and parenting test measurements to identify the exact sport has been analyzed by effectively making use of the application's sport search. However, according to the results of a recapitulation of data utilizing the chi-square, it shows the results as not having a significant difference between parenting styles against youth sports talent. The sport as recommended is a form of complementary information. There are other factors that influence, such as; genetic factors, environment, socioeconomic level, and many more.

\section{CONCLUSION AND SUGGESTION}

Sport aptitude identification for teens between 16-17 years of age, facilitated by Authoritative, Democratic and Permissive parental type indicates seven different kinds of potential sport activities. They are gymnastics, diving, high jump, sprint, trampolining, distance running, shot-put and discus throw. Discerning aptitude identification whilst in consideration of parental types could be seen as the dominant aptitude for the children. Children with a few relatives are dominant in athletics - sprint running and athletics - high jump while children with ideal relatives are dominant in diving.

To attain a high level of success in each sports talent scouting program, it needs to be supported with adequate facilities, infrastructure and funds. In addition to that, participation of the community and parents in specifically improving the physical education in schools and colleges. Also creating an effectively tiered system of matches for athletes. This study examines talent scouting and some talent scoring tests in terms of the differences in types of parental care the child possesses. Although this study still has a lot of shortcomings, it is expected that this research can be used as a talent development strategy and test development for prospective talented athletes.

\section{ACKNOWLEDGMENT}

This research project was approved by the humansubjects research review committee at the Universitas Sebelas Maret, Surakarta, when all the authors were affiliated with the Department of Sport Science at that university.

Special thanks to the Sragen government for providing an opportunity for the collection of data in this study. As well as the whole research team from Department of Sport Science at the Universitas Sebelas Maret. 


\section{REFERENCES}

[1] K. Lindstrom Bremer, "Parental Involvement, Pressure, and Support in Youth Sport: A Narrative Literature Review," $J$. Fam. Theory Rev., 2012.

[2] S. Wuerth, M. J. Lee, and D. Alfermann, "Parental involvement and athletes' career in youth sport," Psychol. Sport Exerc., 2004.

[3] T. E. Dorsch, A. L. Smith, and M. H. McDonough, "Early socialization of parents through organized youth sport," Sport. Exerc. Perform. Psychol., 2015.

[4] K. Hamilton and K. M. White, "Understanding parental physical activity: Meanings, habits, and social role influence," Psychol. Sport Exerc., 2010.

[5] P. A. Sánchez-Miguel, F. M. Leo, D. Sánchez-Oliva, D. Amado, and T. García-Calvo, "The importance of parents' behavior in their children's enjoyment and amotivation in sports," J. Hum. Kinet., 2013.

[6] N. L. Holt, D. E. Black, and K. a. Tamminen, "Rules for parents in youth sport? Opinions of children and their parents," J. Sport Exerc. Psychol., 2007.

[7] J. C. Norcross, J. W. Santrock, L. F. Campbell, T. P. Smith, R. Sommer, and E. L. Zuckerman, Authoritative guide to selfhelp resources in mental health. 2003.

[8] D. Baumrind, R. E. Larzelere, and E. B. Owens, "Effects of preschool parents' power assertive patterns and practices on adolescent development," Parenting, 2010.

[9] D. Gould, L. Lauer, C. Rolo, C. Jannes, and N. Pennisi, "Understanding the role parents play in tennis success: A national survey of junior tennis coaches," British Journal of Sports Medicine. 2006.

[10] S. K. Elliott and M. J. N. Drummond, "Parents in youth sport: what happens after the game?," Sport. Educ. Soc., 2017.

[11] J. Fraser-Thomas, J. Côté, and J. Deakin, "Understanding dropout and prolonged engagement in adolescent competitive sport," Psychol. Sport Exerc., 2008.

[12] A. Abbott, C. Button, G. Pepping, and D. Collins, "Unnatural selection: Talent identification and development in sport," Nonlinear Dynamics. Psychol. Life Sci., 2005.

[13] S. Breitbach, S. Tug, and P. Simon, "Conventional and Genetic Talent Identification in Sports: Will Recent Developments Trace Talent?," Sports Medicine. 2014

[14] R. Vaeyens, A. Güllich, C. R. Warr, and R. Philippaerts, "Talent identification and promotion programmes of olympic athletes," J. Sports Sci., 2009.

[15] C. E. B. Gonçalves, L. M. L. Rama, and A. B. Figueiredo, "Talent identification and specialization in sport: An overview of some unanswered questions," Int. J. Sports Physiol. Perform., 2012.

[16] K. Johnston, N. Wattie, J. Schorer, and J. Baker, "Talent Identification in Sport: A Systematic Review," Sports Medicine. 2018.

[17] S. K. Elliott and M. J. N. Drummond, "During play, the break, and the drive home: the meaning of parental verbal behaviour in youth sport," Leis. Stud., 2017.

[18] J. Tinson, G. Sinclair, and D. Kolyperas, "Sport fandom and parenthood,” Eur. Sport Manag. Q., 2017.

[19] N. V. Lopez et al., "Parent Support and Parent-Mediated Behaviors Are Associated with Children's Sugary Beverage Consumption," J. Acad. Nutr. Diet., 2012.

[20] R. M. Malina, A. D. Rogol, S. P. Cumming, M. J. Coelho E Silva, and A. J. Figueiredo, "Biological maturation of youth athletes: Assessment and implications," Br. J. Sports Med., 2015.

[21] Sugiyono, Statistika Untuk Penelitian. 2012.

[22] D. T. Pearson, G. A. Naughton, and M. Torode, "Predictability of physiological testing and the role of maturation in talent identification for adolescent team sports," J. Sci. Med. Sport, 2006.

[23] D. E. Trussell and S. M. Shaw, "Organized Youth Sport and Parenting in Public and Private Spaces," Leis. Sci., 2012.

[24] D. Tiggelman, M. O. M. Van De Ven, O. C. P. Van Schayck, R. C. M. E. Engels, and E. M. F. Van Sluijs, "Maternal and paternal beliefs, support and parenting as determinants of sport participation of adolescents with asthma," J. Asthma, 2015.

[25] K. M. Sapieja, G. H. Dunn J, and N. L. Holt, "Perfectionism and perceptions of parenting styles in male youth soccer.," $J$. Sport Exerc. Psychol., 2011.

[26] J. C. Kimiecik and T. S. Horn, "Examining the relationship between family context and children's physical activity beliefs: The role of parenting style," Psychol. Sport Exerc., 2012.

[27] J. Rochinha and V. H. Teixeira, "Parenting styles, nutritional intake and anthropometric parameters in children from a football school," Rev. Aliment. Humana, 2013. 